\title{
Sedative-like effect of intraperitoneal GABA administration in the open field test
}

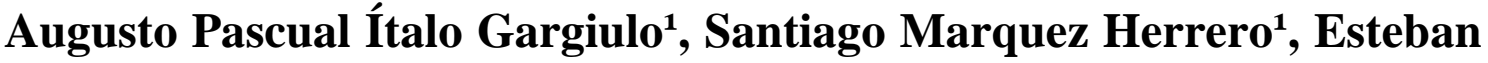 Romanowicz ${ }^{1}$, Manuel Alejandro Guevara ${ }^{1}$, Adriana Inés Landa ${ }^{1}$, José Vicente Lafuente ${ }^{2}$, Humberto Luis Mesones $^{13}$ and Pascual Ángel Gargiulo $^{1 * *}$}

${ }^{1}$ Laboratorio de Neurociencias y Psicología Experimental (CONICET) Facultad de Ciencias Médicas, Universidad Nacional de Cuyo. Mendoza. Argentina. *Email: pagargiulo@hotmail.com.

2Laboratorio de Neurociencias Clínicas y Experimentales (LaNCE). Departamento de Neurociencia. Universidad del País Vasco. España.

${ }^{3}$ Fundación Instituto de Neurobiología (FIDNEU). Buenos Aires. Argentina.

Abstract. Gamma-Amino Butyric Acid (GABA) is the main inhibitor neurotransmitter of the Central Nervous System (CNS). Its peripheral administration has been matter of discussion. On the one hand, it has been reported that it does not cross the Blood-Brain Barrier (BBB), and, on the other hand, it has been associated with multiple therapeutic regimens and supplements by peripheral administration. The aim of the present study is to elucidate the possibility of a central sedative effect when administered peripherally. An experimental cohort of 90-day-old Holtzman male rats weighing 240-270 g was used. It was divided into 2 groups: saline-controls $(n=9)$ and GABA treated rats $(12.5 \mathrm{mg} / \mathrm{kg}, \mathrm{n}=9)$. Both groups were intraperitoneally injected. The motor behavioral patterns displayed in the Opto Varimex (OVM) were studied. Vertical, horizontal, ambulatory and non-ambulatory movements and the number of movements were recorded in an automated way. Horizontal movements constitute the integration of ambulatory and non-ambulatory movements. Student $t$ test was used comparing groups. In this experiment, there were non-significant downward trends in vertical, ambulatory, non-ambulatory and number of movements. Ambulatory and non-ambulatory tendencies acquired significance when treated together as horizontal movements $(p<0.05)$. We may conclude that peripheral administration of GABA produced a decrease of the horizontal movements in the open field test. It may be interpreted as a sedative effect, suggesting a passage of GABA through BBB, with central effects. However, there are several alternative possibilities to explain present findings. Other experiments will elucidate the implications or scope of the present findings.

Keywords: Gamma-amino-butiric acid (GABA); Sedation; Blood brain barrier (BBB); Rat; Behavior.
Received

December 17, 2016

Accepted

December 21, 2016

Released

December 31, 2016

Open Acess Full Text Article

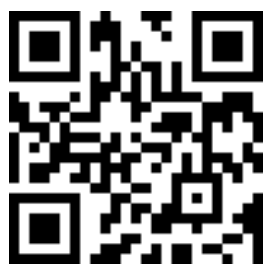

ORCID

(1) 0000-0003-0137-6870

Augusto Pascual Ítalo Gargiulo

(D) 0000-0002-6650-0919

Santiago Márquez Herrero

D $0000-0002-2633-1428$

Esteban Romanowicz

(D) 0000-0001-5545-2037

Manuel Alejandro

Guevara

(D) 0000-0002-7008-2932

Adriana Inés Landa 


\section{Introduction}

\begin{abstract}
Gamma-Amino Butyric Acid (GABA) is the main inhibitor neurotransmitter of the central nervous system (CNS). It comes from the action of glutamate decarboxylase on glutamate. Various forms of this enzyme have been described (see Waagepetersent al., 1999). The fact that various drugs use its receptor has given it relevant clinical importance. This is the case of benzodiazepines and barbiturates, among many others. There are GABA receptors distributed throughout the body, and its role has been proposed in hepatic encephalopathy (Jones et al., 1984).

Its peripheral administration has been the reason for various postures. On the one hand, it has been reported that it does not cross the blood-brain barrier (BBB), and, on the other hand, it has been associated with multiple therapeutic regimens and supplements by peripheral administration (Mesones and Cia, 1985; Halson, 2014).
\end{abstract}

The aim of the present study is to elucidate the possibility of a central sedative effect when administered peripherally. The Opto Varimex (OVM) test was used, since it may serve for detection of modifications in locomotor activity. A decrease in this behavior is classically considered a sign of sedative effects (Maj et al., 1977).

\section{Materials and methods}

An experimental cohort of 90 day-old Holtzman male rats weighing

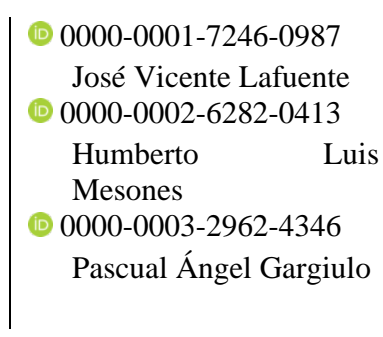

240-270 g was used. It was divided into 2 groups: saline-controls $(n=9)$ and GABA treated rats $(12.5 \mathrm{mg} / \mathrm{kg}, \mathrm{n}=9)$. Animals were intraperitoneally injected 5 min before testing. Saline controls and GABA treated rats run alternatively in the test. One control rat was followed by a treated rat, ensuring the matching of both groups' individuals.

\section{Apparatus and test}

The locomotor behavior of the rats was evaluated in an Opto Varimex Apparatus (OVM, Columbus Instruments). It is a plexiglass box $(50 \times 50 \times 30 \mathrm{~cm})$ with infrared cells that automatically record the different types of movements produced by the rat. Vertical, horizontal, ambulatory and non-ambulatory movements were recorded in an automated way. Horizontal movements constitute the integration of ambulatory and non-ambulatory movements.

\section{Data analysis}

Student t test was used comparing groups. In all cases a value of $\mathrm{p}<0.05$ (two tails) was considered significant. Results are reported as means and standard error of the mean (SEM).

\section{Results}

In this experiment, there were nonsignificant downward trends in vertical. ambulatory, non-ambulatory and number of movements. Ambulatory and nonambulatory tendencies acquired significance when treated together as horizontal movements ( $\mathrm{p}<0.05$, Figure 1$)$. 

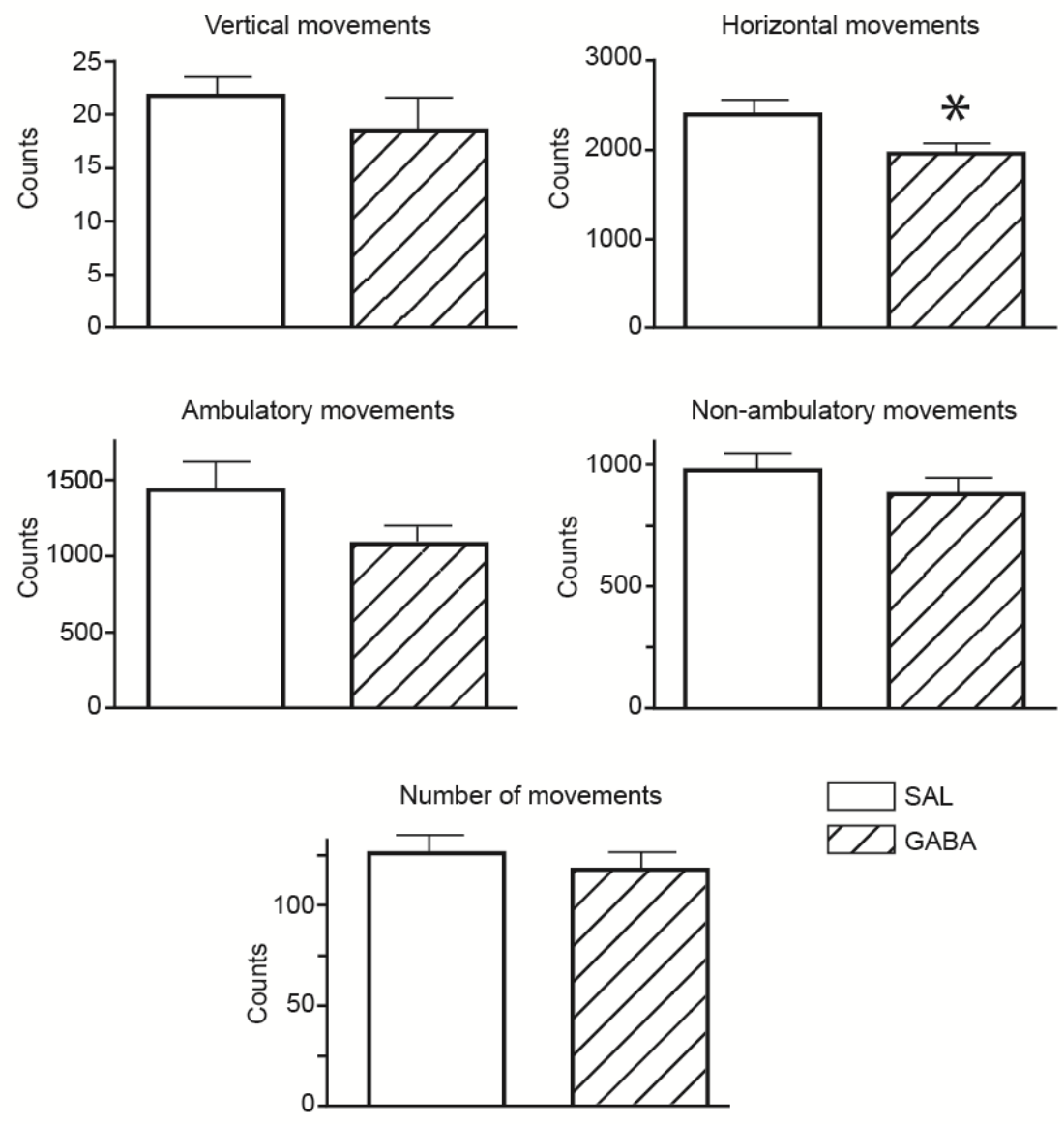

Figure 1. Number of counts obtained in the Opto Varimex (OVM, Columbus Instruments) in vertical movements, horizontal movements, ambulatory movements, non ambulatory movements and number of movements. Comparison was made between saline controls $(n=9)$ and GABA injected rats $(n=9)$, introducing them in alternative form. Values are presented as means \pm standard error of the means (SEM). In all cases a $\mathrm{p}<0.05$ was considered significant.

\section{Discussion}

In the present experiment we observed a significant decrease in ambulatory movements. All other parameters evidenced non significant decreases. The decrease in locomotor activity (ambulatory movements) has been classically interpreted as a sedative effect (Maj et al., 1977). The site of action of GABA administered here to produce this effect may be a matter of discussion. Earlier studies postulated that GABA cannot cross the BBB (see Boonstra et al., 2015). Several initial findings gave support to this idea (Van Gelder and Elliot, 1958; Elliot and Van Gelder, 1958; Roberts et al., 1958; Baxter and Roberts, 1958; Roberts and
Kuriyama, 1968; Kuriyama and Sze, 1971; Knudsen et al., 1988). Subsequent studies showed that GABA could cross the barrier, although in very small amounts (see Boonstra et al., 2015). More sophisticated technology led to different results, allowing sustaining that at least small amount of GABA may go through the BBB (Frey and Löscher, 1980; Löscher, 1981; Löscher and Frey, 1982; Al-Sarraf, 2002; Shyamaladevi et al., 2002). Taking these facts into account, a passage of GABA through the $\mathrm{BBB}$ cannot be ruled out.

On the other hand, the observed action could be due to its effect in areas without barriers. This could be the case in various brain areas, particularly the circumventricular organs (CVOs) and 
hypothalamic nucleuses. A fenestrated vasculature has been described in CVOs, but also in arcuate nucleus (AN) has been described an important vascular permeability (Morita and Miyata, 2012).

The case of AN is very interesting. It has a private milieu. This milieu is closed to neighboring structures. However, it is open to other structure, the infundibular recess, which through some structural arrangements facilitates an influence of cerebrospinal fluid (CSF) to AN. By this way, some peripheral hormones can influence hypothalamic regions. Consequently, a BBB interruption is not necessary to reach them (Rodríguez and Blázquez, 2010).

AN integrates circuits related to stress, and could exert some influence on brain regions protected by the BBB (Sapru, 2013). It should be noted that the AN proyects to nucleus acumbens septi, bed nucleus of the stria terminalis, amygdalin nucleuses and lateral septal nucleus (see Sapru, 2013). Some of these nucleuses have a role in anxiety behaviors (Gargiulo et al., 1996; Martínez et al., 2002, a and b; Llano et al, 2012, 2013; Marinzalda et al., 2014). Furthermore, other several brain areas receive projections from $\mathrm{AN}$, including periaqueductal gray substance, dorsal raphe nucleus and locus coeruleus (Sapru, 2013). This nucleus also has effects on the regulation of blood pressure (Sapru, 2013), and an influence of this type could have had an effect on the decrease in the horizontal movements.

Finally, a role of the peripheral action of GABA cannot be ruled out. The role of GABA in gut has been highlighted, and various studies have been directed at the intestinal microbiota (see Mayer et al., 2015). In the present intraperitoneal injection scheme, although the GABA did not reach the intestinal lumen, the absorption of this drug was made by the portal system, which drains the veins from the intestine, mimicking in this sense physiological conditions.

Several endocrine and neurocrine mechanisms have been involved in brain/gut axis communication, and even a role for gut microbiota signaling has been proposed. By the inverse way, it has been also proposed that the brain may be influencing microbiota through autonomic nervous system (Mayer et al., 2015). Following these ideas, a role for GABA within the gut has been conceived (Blackshaw, 2001), and a role for microbiota has been proposed as psychobiotic, modifying GABA and other gut neurotransmitters (Dinan et al., 2013; Scott et al., 2013; Patterson et al., 2014; Wall et al., 2014).

Recently, a new family of drugs that are already in clinical use has been derived from this compound. This is the case of new derivatives that are postulated to easily pass the BBB, such as Gabapentin (Morris, 1999) and Pregabalin (Feng et al., 2001). It has been asserted that this is a difference with GABA when it is administered systemically.

We may conclude that the peripheral administration of GABA produced a significant decrease of the horizontal movements in the open field test. The effect observed here can be interpreted as a sedative effect, suggesting a passage of GABA through BBB, with central effects. However, there are several alternative possibilities, as it was previously said. This opens the door to discussions and future studies on the effects of peripherally administered GABA. Other experiments will elucidate the implications or scope of the present findings.

\section{Conclusion}

We may conclude that present results allow supporting the idea of a central action of peripherally administered GABA. New studies are necessary to establish definitive conclusions.

\section{Support and aknowledgements}

The present study was supported by the First Neuroscience Grant of the Latin American Technological Corporation Foundation (Fundación Corporación Tecnológica Latinoamericana, FUCOTEL). 
We thank Henry Whittaker for the GABA donation. We thank also to Mrs. Sarita Roitman for her constant support.

\section{Conflict of interest statement}

Authors declare that they have no conflict of interests.

\section{References}

Al-Sarraf, H. Transport of 14C-gammaaminobutyric acid into brain, cerebrospinal fluid and choroid plexus in neonatal and adult rats. Brain. Res. Dev. Brain Res., v. 139, no. 2, p. 121-129, 2002.

Baxter, C. F.; Roberts, E. The gammaaminobutyric acid-alpha-ketoglutaric acid transaminase of beef brain. J. Biol. Chem., v. 233, no. 5, p. 1135-1139, 1958.

Blackshaw, L. A. Receptors and transmission in the brain-gut axis: potential for novel therapies. IV. GABA(B) receptors in the braingastroesophageal axis. Am. J. Physiol. Gastrointest. Liver Physiol., v. 281, no. 2, p. G311-G315, 2001.

Boonstra, E.; de Kleijn, R.; Colzato, L. S.; Alkemade, A.; Forstmann, B. U.; Nieuwenhuis, S. Neurotransmitters as food supplements: the effects of GABA on brain and behavior. Front. Psychol., v. 6, p. 1520, 2015.

Dinan, T. G.; Stanton, C.; Cryan, J. F. Psychobiotics: a novel class of psychotropic. Biol. Psychiatry, v. 74 , no. 10, p. $720-726$, 2013.

Elliot, K. A.; Van Gelder, N. M. Occlusion and metabolism of gamma-aminobutyric acid by brain tissue. J. Neurochem., v. 3, no. 1, p. 28-40, 1958.

Feng, M. R.; Turluck, D.; Burleigh, J.; Lister, R.; Fan, C.; Middlebrook, A.; Taylor, C.; Su, T. Brain microdialysis and PK/PD correlation of pregabalin in rats. Eur. J. Drug Metab. Pharmacokinet., v. 26, no. 1-2, p. 123-128, 2001.

Frey, H. H.; Löscher, W. Cetyl GABA: effect on convulsant thresholds in mice and acute toxicity. Neuropharmacology, v. 9, no. 2, p. 217-220, 1980.

Gargiulo, P. A.; Viana, M. B.; Graeff, F. G.; Silva, M. A.; Tomaz, C. Effects of anxiety and memory of systemic and intra-amygdala injection of 5-HT3 receptor antagonist BRL
46470A. Neuropsychobiology, v. 33, no. 4, p. 189-195, 1996.

Halson, S. L. Sleep in elite athletes and nutritional interventions to enhance sleep. Sports Med., v. 44, Suppl. 1, p. S13-S23, 2014.

Jones, E. A.; Schafer, D. F.; Ferenci, P.; Pappas, S. C. The GABA hypothesis of the pathogenesis of hepatic encephalopathy: current status. Yale J. Biol. Med., v. 57, no. 3, p. 301-316, 1984.

Knudsen, G. M.; Poulsen, H. E.; Paulson, O. B. Blood-brain barrier permeability in galactosamine-induced hepatic encephalopathy. No evidence for increased GABA-transport. J. Hepatol., v. 6, no. 2, p. 187-192, 1988.

Kuriyama, K.; Sze, P.Y. Blood-brain barrier to H3-gamma-aminobutyric acid in normal and amino oxyacetic acid-treated animals. Neuropharmacology, v. 10, no. 1, p. 103-108, 1971.

Llano López, L. H.; Caif, F.; Fraile, M.; Tinnirello, B.; Gargiulo, A. I.; Lafuente, J. V.; Baiardi, G. C.; Gargiulo P. A. Differential behavioral profile induced by the injection of dipotassium chlorazepate within brain areas that project to the nucleus accumbens septi. Pharmacol. Rep., v. 65, no. 3, p. 566-578, 2013.

Llano López, L. H.; Caif, F.; García, S.; Fraile, M.; Landa, A. I.; Baiardi, G.; Lafuente, J. V.; Braszko, J. J.; Bregonzio, C.; Gargiulo, P. A. Anxiolytic-like effect of losartan injected into amygdala of the acutely stressed rats. Pharmacol. Rep., v. 64, no. 1, p. 54-63, 2012.

Löscher, W. Effect of inhibitors of GABA aminotransferase on the metabolism of GABA in brain tissue and synaptosomal fractions. J. Neurochem., v. 36, no. 4, p. 1521-1527, 1981.

Löscher, W.; Frey, H. H. Transport of GABA at the blood-CSF interface. J. Neurochem., v. 38, no. 4, p. 1072-1079, 1982.

Maj, J.; Przewlocka, B.; Kukulka, L. Sedative action of low doses of dopaminergic agents. Pol. J. Pharmacol. Pharm., v. 29, no. 1, p. 11-21, 1977.

Marinzalda, M. L.; Pérez, P. A.; Gargiulo, P. A.; Casarsa, B.S.; Bregonzio, C.; Baiardi, G. Fearpotentiated behaviour is modulated by central amygdala angiotensin II AT1 receptors stimulation. Biomed. Res. Int., v. 2014, Article ID 183248, $\quad 7$ p., 2014. http://dx.doi.org/10.1155/2014/183248

Martínez, G.; Ropero, C.; Funes, A.; Flores, E.; Blotta, C.; Landa, A. I.; Gargiulo, P. A. Effects of selective NMDA and non-NMDA blockade 
in the nucleus accumbens on the plus-maze test. Physiol. Behav., v. 76, no. 2, p. 219-224, 2002a.

Martínez, G.; Ropero, C.; Funes, A.; Flores, E.; Landa, A. I.; Gargiulo, P. A. AP-7 into the nucleus accumbens disrupts acquisition but does not affect consolidation in a passive avoidance task. Physiol. Behav., v. 76, no. 2, p. 205-212, 2002b.

Mayer, E. A.; Tillisch, K.; Gupta, A. Gut/brain axis and the microbiota. J. Clin. Invest., v. 125, no. 3, p. 926-938, 2015.

Mesones, H. L.; Cia, F. M. Correlation between clinical and laboratory data in depression. Therapeutic orientation by means of vitamins and amino acids. Acta Psiquiatr. Psicol. Am. Lat., v. 31, no. 1, p. 25-36, 1985.

Morita, S.; Miyata S. Different vascular permeability between the sensory and secretory circumventricular organs of adult mouse brain. Cell Tissue Res., v. 349, no. 2, p. 589-603, 2012.

Morris, G. L. Gabapentin. Epilepsia, v. 40, Suppl. 5, p. S63-S70, 1999.

Patterson, E.; Cryan, J. F.; Fitzgerald, G. F.; Ross, R. P.; Dinan, T. G.; Stanton, C. Gut microbiota, the pharmabiotics they produce and host health. Proc. Nutr. Soc., v. 73. no. 4, p. 477-489, 2014.

Roberts, E.; Lowe, I. P.; Guth, L.; Jelinek, B. Distribution of $\gamma$-aminobutyric acid and other aminoacids in nervous tissue of various species. J. Exp. Zool., v. 138, p. 313-328, 1958.

Roberts, E.; Kuriyama, K. Biochemicalphysiological correlations in studies of the gamma-aminobutyric acid system. Brain Res., v. 8, no. 1, p. 1-35, 1968.

Rodríguez, E. M.; Blázquez, J. L.; Guerra, M. The design of barriers in the hypothalamus allows the median eminence and the arcuate nucleus to enjoy private milieus: the former opens to the portal blood and the latter to the cerebrospinal fluid. Peptides, v. 31, no. 4, p. 757-776, 2010.
Sapru, H. N. Role of the hypothalamic arcuate nucleus in cardiovascular regulation. Auton. Neurosci., v. 175, no. 1/2, p. 38-50, 2013.

Scott, L. V.; Clarke, G.; Dinan, T. G. The braingut axis: a target for treating stress-related disorders. Mod. Trends Pharmacopsychiatry, v. 28, p. 90-99, 2013. http://dx.doi.org/10.1159/000343971

Shyamaladevi, N.; Jayakumar, A. R.; Sujatha, R.; Paul, V.; Subramanian, E. H. Evidence that nitric oxide production increases gamma-amino butyric acid permeability of blood-brain barrier. Brain Res. Bull., v. 57, no. 2, p. 231-236, 2002.

Van Gelder, N. M.; Elliot, K. A. Disposition of gamma-aminobutyric acid administered to mammals. J. Neurochem., v. 3, no. 2, p. 13943, 1958.

Waagepetersen, H. S.; Sonnewald, U.; Schousboe, A. The GABA paradox: multiple roles as metabolite, neurotransmitter, and neurodifferentiative agent. J. Neurochem., v. 73, no. 4, p. 1335-1342, 1999.

Wall, R.; Cryan, J. F.; Ross, R. P.; Fitzgerald, G. F.; Dinan, T. G.; Stanton, C. Bacterial neuroactive compounds produced by psychobiotics. In: Lyte, M.; Cryan, J. F. (Eds.). Microbial endocrinology: the microbiota-gutbrain axis in health and disease. New York: Springer, 2014. p. 221-239. (Advances in Experimental Medicine and Biology: Microbial Endocrinology, v. 817). http://dx.doi.org/10.1007/978-1-4939-0897-4_10

License information: This is an open-access article distributed under the terms of the Creative Commons Attribution License, which permits unrestricted use, distribution, and reproduction in any medium, provided the original work is properly cited. 